\title{
The effect of organic matter on the structure of clay soils
}

\section{P. BOEKEL}

Institute for Soil Fertility, Groningen, Netherlands

\section{Summary and conclusions}

The effect of organic-matter content on intrinsic and actual soil structure was studied in a great number of plots under practical conditions. Figures relating to the intrinsic soil structure were obtained by determining the lower plastic limit, the upper plastic limit and the moisture percentage at $\mathrm{pF}=2$ (field capacity). The actual soil structure was determined by measuring the pore space and air content and by visual estimation.

The effect of organic manuring on the actual soil structure was studied in a number of experimental fields with town refuse, farmyard manure, green manuring and ley farming.

An increase in organic-matter content decreases the slaking sensitivity of silt soils, increases the resistance to plastic deformation caused by the mechanical forces acting on heavy clay soils under wet conditions and improves the actual soil structure. Concerning the latter effect, the visual estimation increases with $0,6-0,7$ points per \% organic matter, but varies somewhat according to the nature of the organic matter.

Data were obtained on the organic-matter content required to prevent slaking, to give a good resistance to mechanical structure deterioration and to provide an actual soil structure conducive to plant growth. This led to the conclusion that in order to obtain a soil structure suitable for good plant growth the lowest organic-matter percentage is required on a clay soil in which the percentage of particles $<16 \mu$ ranges from 15 to 30 , depending on the soil treatment.

\section{Introduction}

It is generally recognised that a regular application of organic material is necessary to obtain or maintain a good structure on clay soils. The effect of organic matter on the stability of soil aggregates was studied by Baver (1956), PeerlKamp (1950) and HEINONEN (1955). In most cases the stability was determined by wet-sieving methods. These usually afford some idea of the resistance of sandy clay soils and loams to erosion and slaking, but do not give much information on the structure stability of heavy clay soils.

Boekel and Peerlokmp (1956) found that the deterioration of the structure of heavy clay soils is not caused by the dispersing action of water, but mainly by a plastic deformation of the wet soil as a result of mechanical forces. Wet-sieving does not provide characteristic figures on this mechanism.

It is therefore preferable to use other methods in studying the effect or organic matter on the structure of heavy clay soils. Determination of soil consistency (BOEKEL, 1959) and soil porosity (KuIPERS, 1955, 1961) seems to have practical significance in this connection.

Received for publication 15th March, 1963. 
Hitherto no figures were available on the effect of organic matter on these characteristics. We therefore began this investigation some years ago in order to gain a more accurate picture of soil-structure problems on clayey soils and the effect of organic matter on the structure of such soils.

\section{Methods}

The methods used for determining different aspects of soil structure and other properties of the soil were as follows :

a. visual evaluation of soil structure (St-number) as described by PeErlkamp (1959).

The St-number of some twenty soil blocks dug from the soil, was estimated by considering the following features: size and shape of the aggregates, cohesion of soil particles, porosity of the aggregates and the entire tilth, root development and dispersion of the soil surface. An St-number is estimated by means of a scale ranging from 1 (very poor structure) to 10 (ideal structure);

b. the determination of pore space and air content at the moment of sampling and at a moisture content corresponding to $\mathrm{pF} 2$ (KuIPERs, 1955, 1961). Core samples were taken in the field, and the weight of the original wet samples, the samples brought to $\mathrm{pF} 2$ and the oven-dry samples was determined in the laboratory. From this data it was possible to deduce the moisture content at the moment of sampling and at $\mathrm{pF}$ 2. By determining the specific gravity of the soil material it was possible to calculate the volume percentages of soil and pore space. The difference between pore space and moisture content represented the air content;

c. determination of soil consistency as described by BoEKEL (1959). For this purpose, lower plastic limit, upper plastic limit and moisture content at pF 2 were determined;

d. determination of soil texture according to HooghoudT (1945). The soil was pretreated with $\mathrm{H}_{2} \mathrm{O}_{2} 40 \%$ and $\mathrm{HCl} 1 \mathrm{~N}$ and then peptized with a solution of $\mathrm{Na}_{4} \mathrm{P}_{2} \mathrm{O}_{7} 10 \mathrm{H}_{2} \mathrm{O}$. The fraction $<16 \mu$ was determined by pipetting, and the fineness of the sand by sieving the dry material $>50 \mu$ with a Rotap sieving machine. The $\mathrm{U}$-value was calculated as the mean weight of the specific surface of the various sand fractions;

c. organic-matter content determinations by the Kurmies method (MEBIUs et al., 1957) by oxidizing the organic matter with chromic acid.

These analyses were employed in studies undertaken for other purposes, viz. :

1. a soil-cultivation study, for which a great number of soil samples were taken systematically from marine clay soils varying in clay content, fineness of sand and organic-matter content;

2. a soil-fertility analysis made by FerRari (1952) in a river clay district (Bommelerwaard), for which organic-matter percentages and soil structures were determined;

3. an investigation of the soil structure of marine clay soils in the neighbourhood of Godlinze in the north of the province of Groningen (Boskma and Sluissmans, 1956) and

4. a study of the effect of organic matter on soil fertility of clay soils in a great number of experimental fields with town refuse (KorTLEVEN, 1956), farmyard manure (Grootenhuis and WisselinK, 1954) and ley farming (GrootenhuIs, 1961).

Methods a to e were not applied in all these studies, but the relation between certain 
of them, e.g. between the visual estimation of soil structure and the percentage of air content at $\mathrm{pF} 2$, was known, so that it was possible to translate one method in terms of another (FIG. 1).

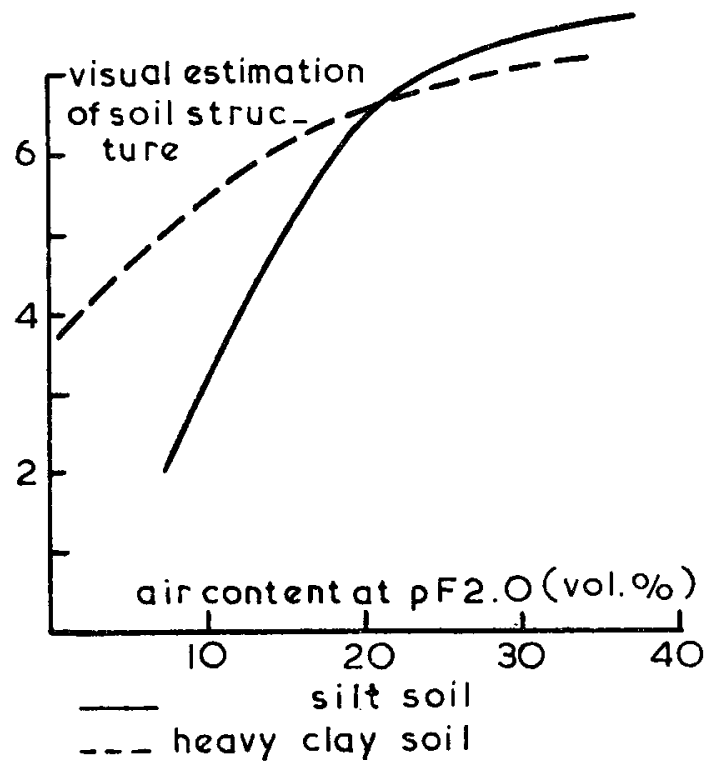

FIG. 1.

Relation between visual-structure estimation and air content at $\mathrm{pF} 2$

\section{Structure of clay soils}

In addition to the results concerning the relationship between organic matter and soil structure, information was obtained on the structural state of several clay soils. The air contents at $\mathrm{pF} 2$ found in silty and heavy clay soils during the vegetation period in 1959, 1960 and 1961 are plotted in FIG. 2. In silty soils air contents of from 10 to 20 volume \% were found with no great differences between the three years. Generally speaking, the structural state of these soils was fairly good, despite the fact that most of them are somewhat sensitive to slaking. This is due to the fact that their workability is quite good. It is easy to reduce these soils to a good structural state by means of tillage. On heavy clay soils however, the structure was usually poorer. The mean air content was lower and the variation during the observation period somewhat greater. This must be due to the small resistance to mechanical forces, especially under wet conditions. Moreover these soils are readily compressed, causing a dense particle arrangement. Owing to the poor workability it is very difficult to reduce these soils to a good structural state, especially after a wet autumn and a mild winter such as occurred in 1958. But under favourable conditions (e.g. after a dry autumn and a winter with some frost as was experienced at the end of 1959) a fairly good soil structure may be obtained.

\section{Effect of organic-matter content on the intrinsic soil structure}

The effect of the organic-matter percentage on the lower plastic limit, the upper 
FIG. 2. Air contents on heavy clay and silt soils

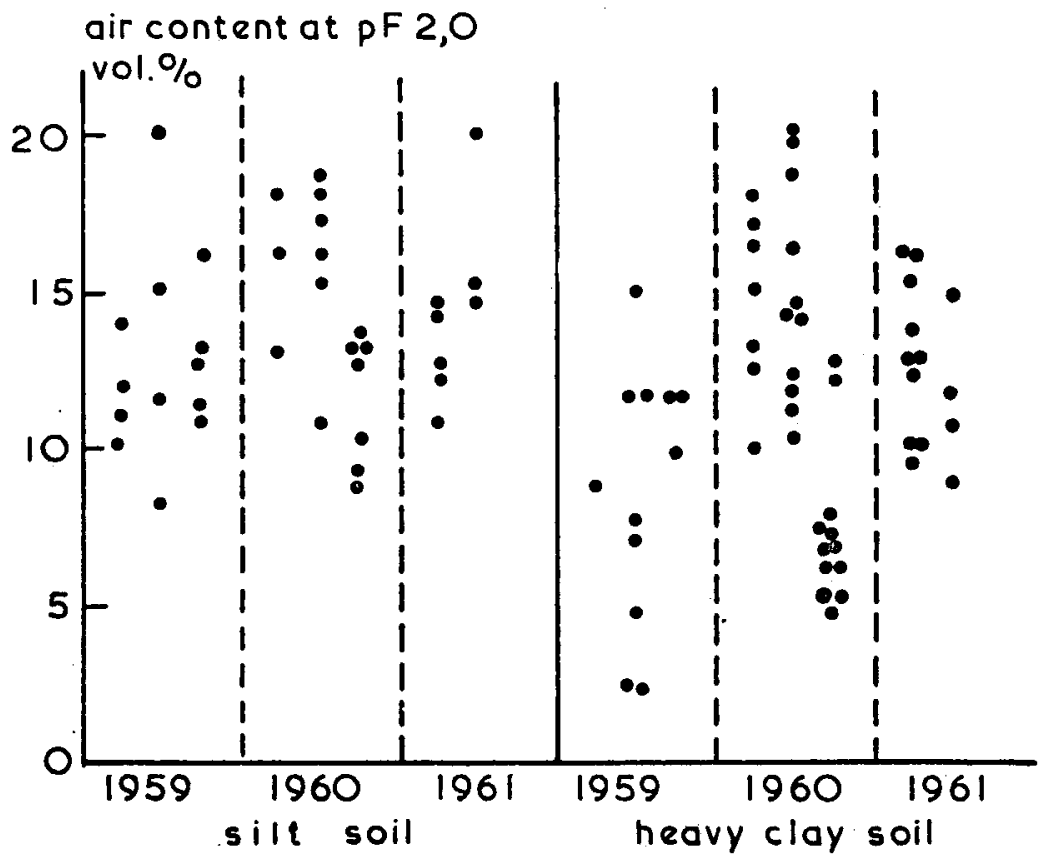

plastic limit and the moisture percentage at $\mathrm{pF} 2$ was studied. The location of the point pF 2 ("field capacity") with respect to the upper plastic limit gives some information on the sensitivity of the soil to slaking. If "field capacity" is about the same or somewhat greater than the upper plastic limit, the soil slakes and begins to flow under wet conditions. But if the upper plastic limit is much higher than "field capacity" there will be no appreceable slaking.

FIG. 3 shows the effect of organic-matter content on upper plastic limit and „field capacity" for soils varying in clay content and fineness of sand (U-value).

The "field capacity" at a certain organic-matter percentage increases with respect to the upper plastic limit of the same organic-matter content when the fineness of the sand fraction (U-value) increases and the clay content decreases. Hence these changes in texture abet soil slaking. When the organic-matter content increases, the upper plastic limit increases more than "field capacity", resulting in a good effect on soil structure. From this it may be included that silty soils with a fine-textured sand fraction have the greatest sensitivity to slaking and need a fairly high organicmatter content to overcome this. In general, clay soils with a clay content of $40 \%$ and over are not subject to serious slaking. These soils, however, are sensitive to plastic deformation as a result of mechanical forces, resulting in a dense structure and poor workability. Information on this sensitivity is obtained from the location of "field capacity" with respect to the lower plastic limit. A moisture percentage at pF 2 which is much higher than the lower plastic limit is an indication of slight resistance to mechanical forces and to poor workability of the soil under normal moist and wet conditions. 
P. BOEKEL

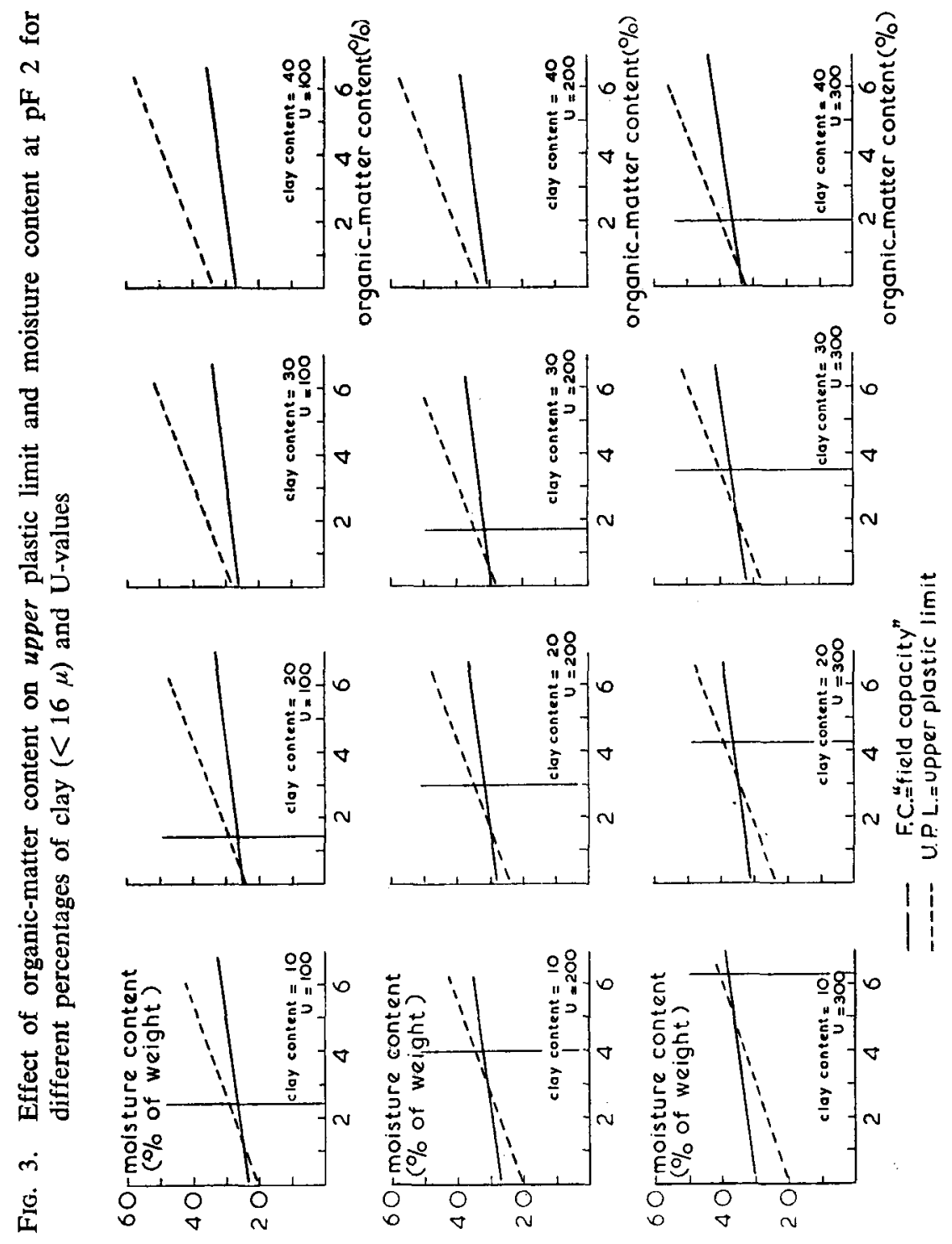


FIG. 4 shows the effect of organic-matter content on the lower plastic limit and "field capacity" of soils differing in clay content and fineness of sand.

At a certain organic-matter percentage an increase of clay content and fineness of sand results in an increase of the height of "field capacity" above the lower plastic limit. This means that there is an unfavourable influence on soil structure. But an increasing organic-matter content has a favourable effect as it increases the lower plastic limit more than the moisture content at $\mathrm{pF} 2$.

\section{Effect of organic-matter and organic dressings on the actual soil structure}

It will be clear that crop growth is affected by the spatial arrangement of the soil during the vegetation period, viz. the actual soil structure. It is therefore important to know the effect of organic matter on this aspect of soil structure. Results concerning this relationship were obtained during the studies on soil fertility in the Bommelerwaard and in the north of Groningen. Soil structure, visually estimated, is plotted against the organic matter percentage in FIG. 5 .

An increase in organic-matter content of one per cent improved soil structure by 0,25 (Godlinze) $-0,60$ (Bommelerwaard) of a point. These relationships were shown to be significant. The reason for the difference between the results of these two regions is not quite clear. Conditions during the years in question may have played a material part, and the difference in crop (potatoes in Bommelerwaard, several crops in north Groningen) may have had an effect. It is also striking that the variety of soil structure at a certain level or organic-matter content is so great. Apparently a soil with a low organic-matter content does not always have a poor soil structure, but may also be in a fairly good structural condition. In the same way, a soil with a high organic-matter content does not always exhibit a good actual soil structure, but in many cases it has a rather poor spatial arrangement. This must be due to such technical factors as time and method of cultivation and other soil treatments, since the soil properties (clay content, lime state and fineness of sand) only appeared to be responsible for a very small part of the variety.

This means that to some extent the farmer is able to offset the disadvantages of a low organic-matter content with regard to soil structure by means of good cultivation and careful treatment of the soil.

TABLE 1 shows the effect of such organic dressings as town refuse, farmyard manure, green manuring and ley farming obtained from different experimental fields.

On experimental fields dressed with town-refuse compost an increase in organicmatter content of 0,17 was obtained, resulting in increases in the pore space of the air content of 0,8 and 1,1 vol. \% respectively. This means that a $1 \%$ increase in organic-matter content corresponds to increases in pore space and air content of 5 and 6 vol. \% respectively. It can be seen from FIG. 1 that this change in air percentage corresponds to an increase of about 0,8 points in the visual structure estimation.

On the horticultural experimental fields a $2 \frac{1}{2} \%$ increase in organic-matter content was obtained and an improvement of $1 \frac{1}{2}$ points in the soil structure in the treatments with sewage sludge, as determined by visual estimation. In this case a $1 \%$ increase in the organic-matter content results in a soil-structure improvement of 0,6 points.

Dressings of farmyard manure, which increased the organic-matter content by about $1 \%$, improved the soil structure by $1 / 4$ point. On experimental fields dressed with

Neth. J. agric. Sci., Vol. 11 (1963) No. 4 (August) 
P. BOEREL

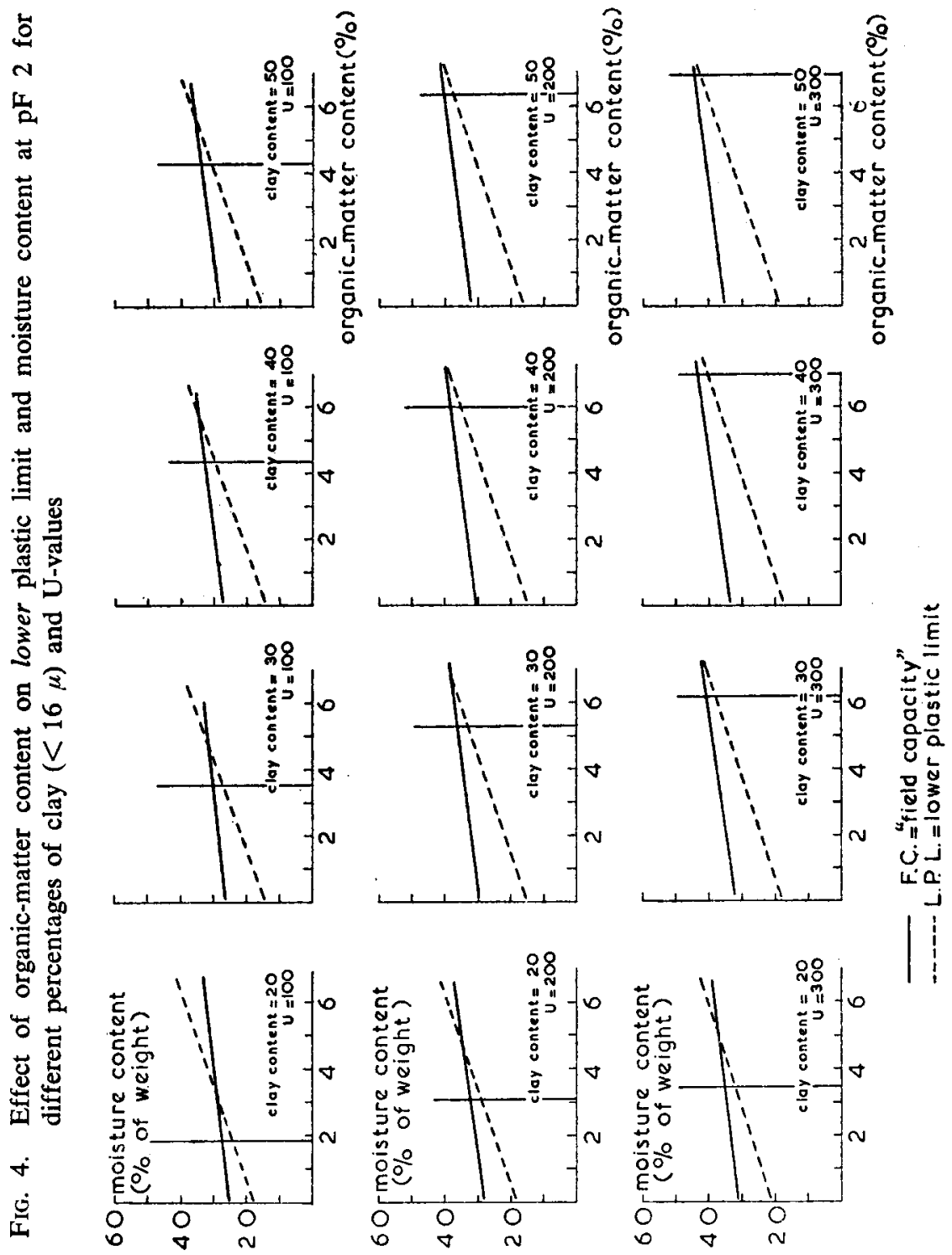


THE EFFECT OF ORGANIC MATTER ON THE STRUCTURE OF CLAY SOILS

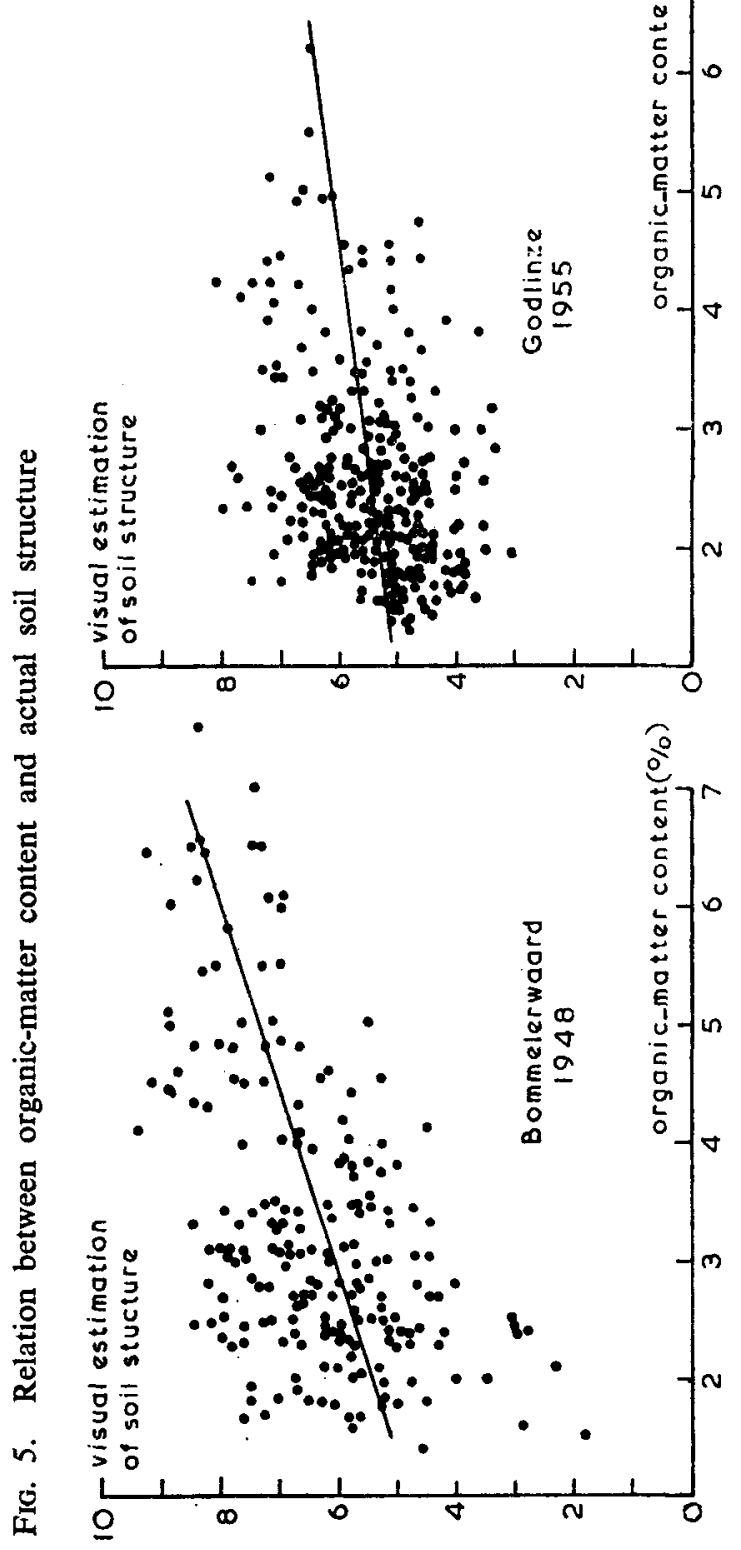

Neth. J. agric. Sci., Vol. 11 (1963) No. 4 (August) 
P. BOEKEL

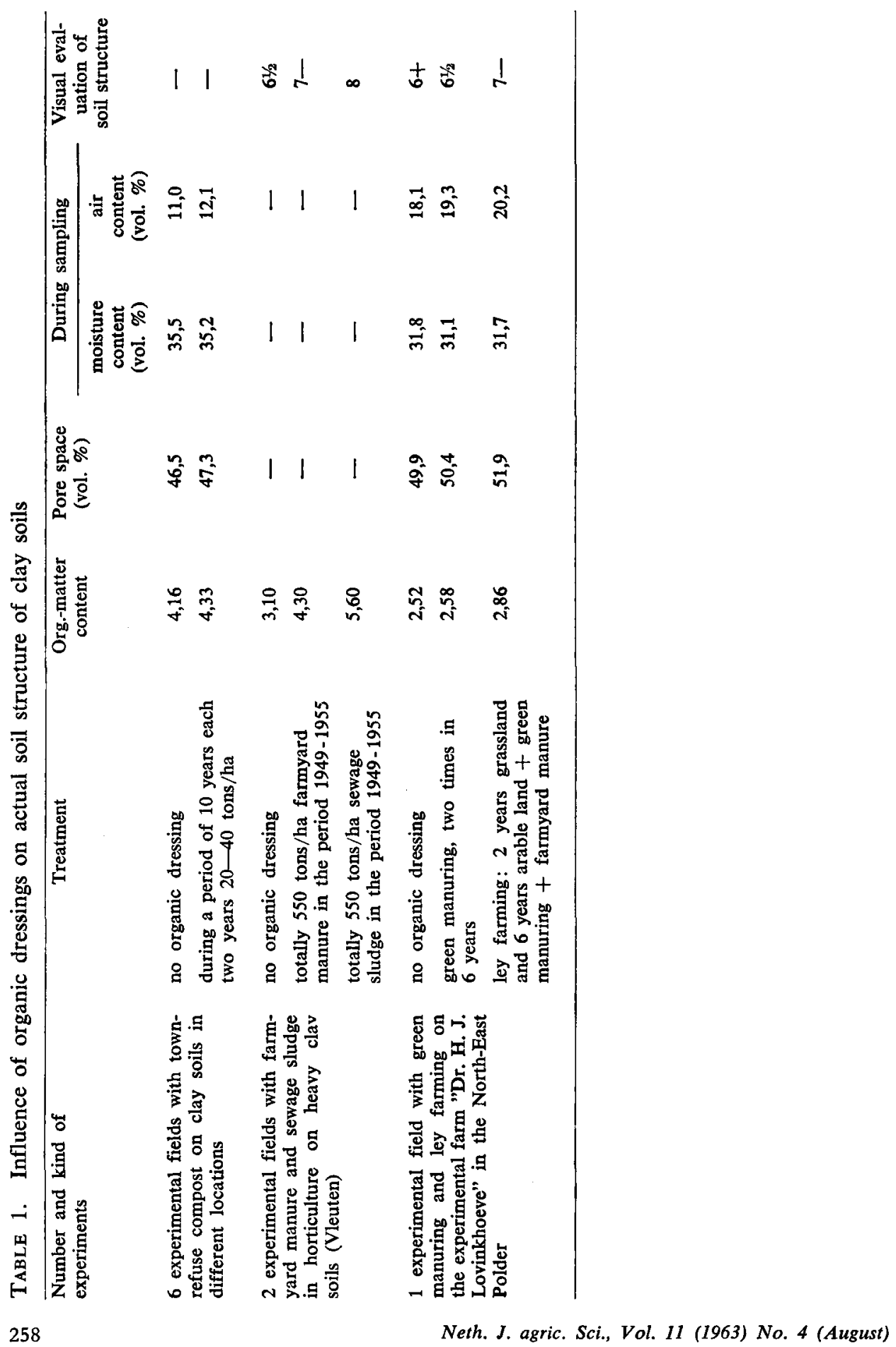


10 tons of farmyard manure per ha per annum practically no effect on soil structure was found.

On the experimental field in the North-East Polder organic-matter content increased by $0,34 \%$ and soil structure by $1 / 2$ point after one cycle of ley farming, together with some green and farmyard manuring. Pore space and air content both increased by about 2 vol. \%. The effect on soil structure of the organic matter obtained by ley farming is about the same as that of the organic matter derived from town refuse and seems to be somewhat greater than that of the organic matter obtained from sewage sludge. Although green manuring did not have a significant effect on the organic-matter percentage, it had a good effect on soil structure. This must be due to such adventitious effects as covering the soil for a longer period, making the soil somewhat drier during a wet period and binding the soil particles by the roots.

Summarizing all these results, we obtain a certain fluctuation $(0,25-1,50$ points visually estimated structure per $1 \%$ of organic matter) in the effect of soil organic matter on the structure of clay soils, mainly depending on the kind of organic material applied. The effect of farmyard manure is small compared with that of town refuse and green manuring appears to be very favourable for the soil structure. There are indications that the effect of organic material on soil structure also depends on the nature of the soil to which it is applied, although there is not sufficient data available to enable us to draw a reliable conclusion. The mean effect found in this case is an increase of the visual estimated soil structure with $0,6-0,7$ points per $\%$ of soil organic matter.

\section{Practical use of the results}

We concluded from FIG. 3 that soils with a low clay content and a fine-textured sand fraction are particularly prone to slaking.

A fairly high percentage of organic matter is needed to prevent this unfavourable effect. If we assume that slaking does not occur when the upper plastic limit exceeds the "field capacity" by $3 \%$ or more by weight (see the vertical lines in FIG. 3), the minimum organic-matter percentages required in this case for soils varying in clay content and fineness of sand can be inferred from fIG. 3. They are shown in TABLE 2.

TABLE 2. Minimum organic-matter percentages required to prevent slaking of soils, varying in clay content and fineness of sand

\begin{tabular}{cccc}
\hline Clay content & \multicolumn{3}{c}{ Fineness of sand (U-value) } \\
\cline { 2 - 4 } & 100 & 200 & 300 \\
\hline 10 & 2,5 & 4,0 & 6,2 \\
20 & 1,5 & 3,0 & 4,2 \\
30 & 0,0 & 1,8 & 3,5 \\
40 & 0,0 & 0,0 & 2,0 \\
\hline
\end{tabular}

In the same way, information can be obtained on the minimum organic-matter percentages required to give sufficient resistance to plastic deformation by mechanical forces and a good workability. If it is assumed that these conditions will occur when 
the "field capacity" only exceeds the lower plastic limit by $3 \%$ (see FIG. 4), the following organic-matter percentages are obtained (TABLE 3).

TABLE 3. Minimum organic-matter percentages required for having a good resistance against plastic deformation by mechanical forces and a good workability, in soils varying in clay content and fineness of sand

\begin{tabular}{crcc}
\hline Clay content & \multicolumn{3}{c}{ Fineness of sand (U-value) } \\
\cline { 2 - 4 } & 100 & 200 & 300 \\
20 & 1,9 & 3,1 & 3,5 \\
30 & 3,5 & 5,5 & 6,2 \\
40 & 4,3 & 6,0 & 6,9 \\
50 & 4,3 & 6,3 & 6,9 \\
\hline
\end{tabular}

After the minimum organic-matter contents shown in TABLES 2 and 3 have been plotted against the corresponding clay contents (as is done in FIG. 6) we can conclude that soils with a clay content (particles $<16 \mu$ ) of about $20 \%$ need the lowest organic-matter content both in order to prevent slaking and to obtain a sufficient resistance to deformation, independently of the $U$-value. Heavier soils require a higher content of organic matter in order to maintain their mechanical resistance, and lighter soils have to be richer in humus to prevent slaking. It is clear that the relation between the required organic-matter content and the clay content depends on the assumption made on the difference required between "field capacity" and upper and lower plastic limit. These assumptions which may also affect the clay content at which the required organic-matter content is minimal, should be checked by observations in the field.

The question now arises as to how far these requirements with respect to organic-

FIG. 6. Organic-matter percentages required to prevent slaking and provide a good resistance to plastic deformation by mechanical forces and a good workability

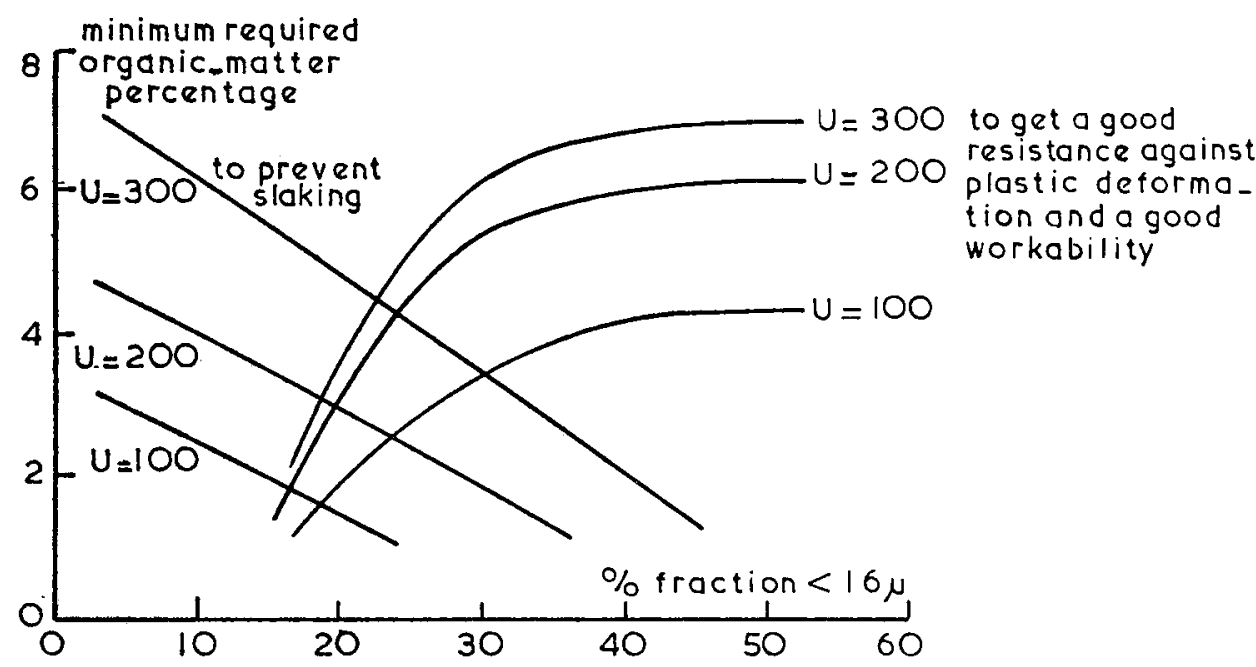


matter content, made from the pedological point of view, correspond to the percentages required to obtain the most favourable physical conditions for plant growth.

Another study (BoEkEL, 1963 a) has shown that on clay soils an air content at pF 2 of about 15 vol. \% is required to obtain a good plant growth. This air content at pF 2 corresponds to a visual structure estimation of about $51 / 2$.

In order to ascertain what organic-matter content is required for a soil structure which gives a good plant growth the clay content should be taken into account. It was found by BOEKEL (1963 b) that the visual estimated soil structure increased by about 0,4 points when the clay content decreased by $10 \%$. This means that in order to obtain a good soil structure a heavy clay soil needs a higher percentage of organic matter than a sandy clay soil.

The only missing link is the level of soil structure from which to start. It is known that owing to variations in the weather and the treatment of the soil, soil structure changes considerably from year to year. We obviously require a good soil structure every year and must therefore start from the most unfavourable conditions of weather, cultivation and treatment. This situation was approximately realised in the Godlinze experiment, which makes it possible to use FIG. $5 \mathrm{~b}$ as a starting point. The mean percentage of particles $<16 \mu$ on these clay soils is $30 \%$. Fig. $5 \mathrm{~b}$ shows that the structure of a soil with $2 \%$ organic matter is evaluated visually as 3 when the soil is very poorly treated and as $51 / 4$ when the treatment is fairly normal.

FIG. 7 is constructed with the aid of these data and the mean effect of the organicmatter percentage on the actual soil structure as given at the end of section 5 .

FIG. 7. Organic-matter percentages required on differently treated clay soils with different clay contents $(<16 \mu)$ in order to obtain an actual soil structure sufficiently good for plant growth

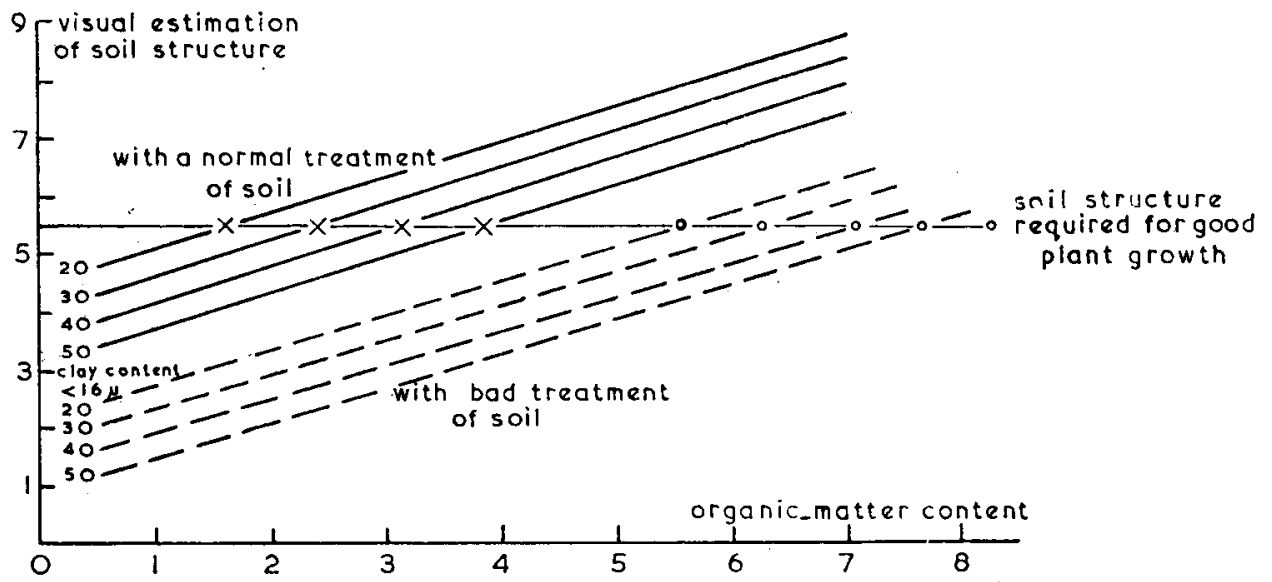

This figure shows that a heavy clay soil $(50 \%<16 \mu)$ which is treated in an unfavourable way requires about $7-8 \%$ organic matter to obtain a good soil structure of $51 / 2$ which is sufficient for good plant growth. With more careful cultivation and other soil treatments, an organic-matter percentage of about $4 \%$ will be sufficient. Soils with a lower clay content require a lower percentage of organic matter. Comparing (FIG. 8) these percentages of organic matter with those required on soils 
FIG. 8. Organic-matter percentages required by soils with different clay contents to prevent slaking, to ensure good mechanical resistance and workability and to obtain an actual structure sufficient for good plant growth with bad and normal soil treatments

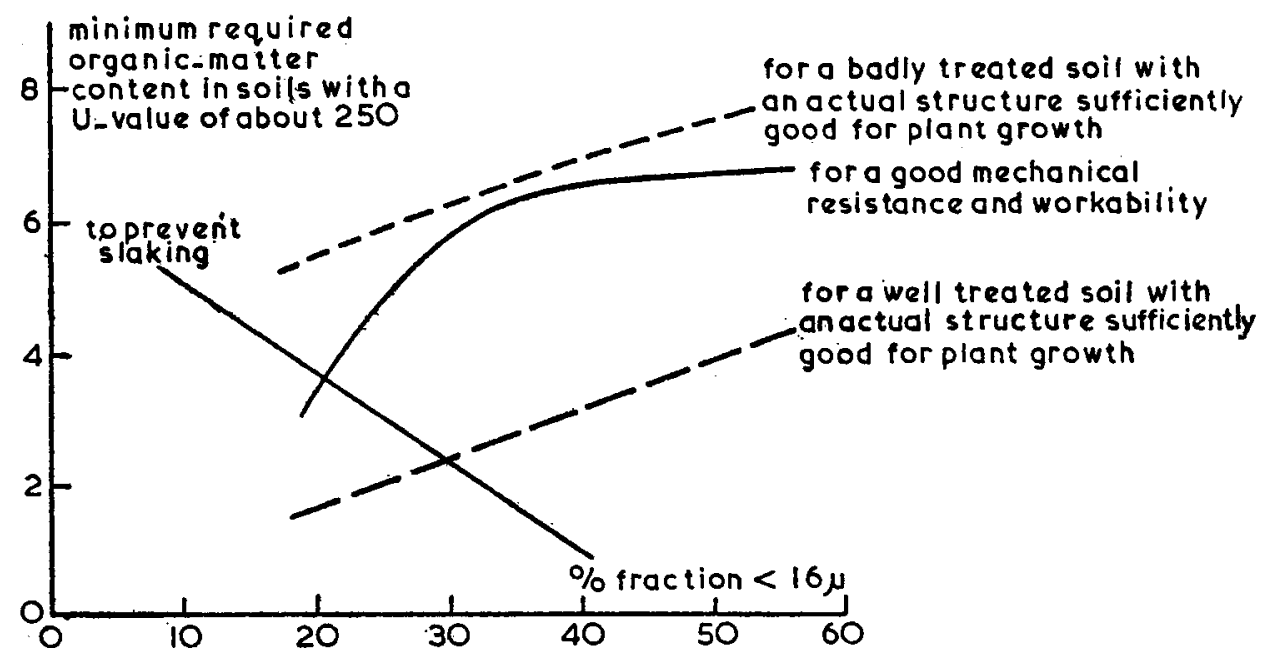

with U-value 250 to obtain the most favourable state of slaking and resistance to mechanical forces (see FIG. 6), it can be seen that there is fairly good agreement between the percentages required to obtain a good actual structure after a fairly poor treatment of the soil and those required to obtain sufficient mechanical resistance and a good workability. The lowest organic-matter percentage required to avoid slaking and obtain an actual structure which is sufficient for good plant growth despite poor soil treatment is obtained on soils with about $13 \%$ particles $<16 \mu$ and amounts to $41 / 2 \%$. If slaking is to be avoided and the soil is to have a good mechanical resistance and workability, the lowest organic-matter percentage is $31 / 2 \%$ on soils with about $20 \%$ particles $<16 \mu$ if the soil treatment is fairly good. If mechanical resistance and workability are less important factors and the disadvantages of an unfavourable state thereof on plant growth can be corrected by a more intensive and careful treatment, the lowest organic-matter content (about $21 / 2 \%$ ) is required on soils with a clay content of about $30 \%$. On soils with a lower U-value than 250 , the required percentages of organic matter are somewhat lower.

This study provided some information on the organic-matter percentages required for favourable physical properties on different clay soils under different conditions. It will be clear that these properties are not the only factors that determine the organic-matter percentage required and that the nitrogen economy may possibly make other demands. 
Baver, L. D.

Boekel, P.

and P. K. PeErl-

KAMP

BoskmA, K., and

C. M. J. Sluijsmans

FerRarI, Th. J.

and C. M. J. SluiJsMANS

Grootenhuis, J. A.

LINK

and G. J. WISSE-

Heinonen, R.

Hooghoudt, S. B.

Kortleven, J.

KUIPERS, $\mathbf{H}$.

Mebius, L. J., A. DekKer and J. TEN HAVE

Peerlkamp, P. K.

\section{I T E R A T U R E}

1956 Soil physics. John Wiley \& Sons, Inc., New York; Chapman \& Hall Ltd., London.

1959 Evaluation of the structure of clay soils by means of soil consistency. Proc. Intern. Symp. on Soil Structure Ghent, May 28-31, 1958, Meded. Landb.hogesch. Opzoek.stations Staat Gent. Deel XXIV, No. 1, 363-367.

1963a Soil structure and plant growth. Neth. J. agric. Sci. 11, $120-127$.

1963b Invloed van de zwaarte op enkele fysische eigenschappen van de grond. Landbouwk. Tijdschr. 75, 507-518.

1956 Soil consistency as a factor determining the soil structure of clay soils. Neth. J. agric. Sci. 4, 122-125.

1956 Rapport van een onderzoek over de structuur van de grond in de Ruilverkaveling Godlinze (Gr.) Internal report I.B., Groningen.

1952 Een onderzoek over de stroomruggronden van de Bommelerwaard met als proefgewas de aardappel. Versl. Landbouwk. Onderz. No. 58.1.

1955 Mottling and magnesium-deficiency in oats and their dependance on various factors. Plant and Soil. VI, 3: 262-299.

1961 Invloed van gescheurde kunstweiden op het produktievermogen van zavelgronden. Stikstof. 30, 242-252.

1954 Verslag van het onderzoek op de bodemvruchtbaarheidspercelen, aangelegd onder auspiciën van de bodemvruchtbaarheidscommissie. Rapport I.B., Groningen, No. V.

1955 Soil aggregation in relation to texture and organic matter. Agrogeol. Julk. No. 64, 1-17.

1945 Bijdragen tot de kennis van enige natuurkundige grootheden van de grond. 9. Een gecombineerde zeef- en pipetmethode voor de bepaling van de granulaire samenstelling van gronden. Versl. Landbouwk. Onderz. No. 50 (13) A.

1961 Organische stof en humus. Landb.voorl. 18, 2: 130-135.

1956 Proeven met stadsvuilcompost I. Invloed van stadsvuilcompost op het gewas. Versl. Landbouwk. Onderz. No. 61.12.

1961 Water content at pF 2 as a characteristic in soil cultivation research in the Netherlands. Neth. J. agric. Sci. 9, 27-35.

1955 Een streekonderzoek, gericht op de factoren bodemstructuur en stikstofbemesting. Versl. Landbouwk. Onderz. No. 61.9, p. 21.

1957 "De methode Kurmies", een snelle en betrouwbare titratiemethode voor de bepaling van het humusgehalte van de grond. Chem. Weekblad. 53, p. 291.

1950 De invloed van organische stof op de bodemstructuur en winderosie. Landbouwk. Tijdschr. 62, 594-611.

1959 A visual method of soil structure evaluations. Proc. Intern. Symp. on Soil Structure Ghent, May 28-31, 1958, Meded. Landb.hogesch. Opzoek.stations Staat Gent. Deel XXIV, No. $1,216-221$. 